\title{
The impact of North Atlantic sea surface temperature errors on the simulation of North Atlantic European region climate
}

Article

Published Version

Keeley, S., Sutton, R. and Shaffrey, L. (2012) The impact of North Atlantic sea surface temperature errors on the simulation of North Atlantic European region climate. Quarterly Journal of the Royal Meteorological Society, 138 (668). pp. 1774-1783. ISSN 1477-870X doi:

https://doi.org/10.1002/qj.1912 Available at https://centaur.reading.ac.uk/27752/

It is advisable to refer to the publisher's version if you intend to cite from the work. See Guidance on citing.

To link to this article DOI: http://dx.doi.org/10.1002/qj.1912

Publisher: Royal Meteorological Society

All outputs in CentAUR are protected by Intellectual Property Rights law, including copyright law. Copyright and IPR is retained by the creators or other copyright holders. Terms and conditions for use of this material are defined in the End User Agreement. 


\section{CentAUR}

Central Archive at the University of Reading

Reading's research outputs online 


\title{
RMetS
}

Royal Meteorological Society

\section{The impact of North Atlantic sea surface temperature errors on the simulation of North Atlantic European region climate}

\author{
S. P. E. Keeley, ${ }^{\star}$ R. T. Sutton and L. C. Shaffrey \\ Department of Meteorology, University of Reading, UK
}

${ }^{*}$ Correspondence to: S. P. E. Keeley, NCAS-Climate, Department of Meteorology, University of Reading, Earley Gate, PO Box 243, Reading RG6 6BB, UK. E-mail: s.p.e.keeley@reading.ac.uk

\begin{abstract}
Current state-of-the-art climate models fail to capture accurately the path of the Gulf Stream and North Atlantic Current. This leads to a warm bias near the North American coast, where the modelled Gulf Stream separates from the coast further north, and a cold anomaly to the east of the Grand Banks of Newfoundland, where the North Atlantic Current remains too zonal in this region. Using an atmosphere-only model forced with the sea surface temperature (SST) biases in the North Atlantic, we consider the impact they have on the mean state and the variability in the North Atlantic European region in winter. Our results show that the SST errors produce a mean sea-level pressure response that is similar in magnitude and pattern to the atmospheric circulation errors in the coupled climate model. The work also suggests that errors in the coupled model storm tracks and North Atlantic Oscillation, compared to reanalysis data, can also be explained partly by these SST errors. Our results suggest that both the error in the Gulf Stream separation location and the path of the North Atlantic Current around the Grand Banks play important roles in affecting the atmospheric circulation. Reducing these coupled model errors could improve significantly the representation of the large-scale atmospheric circulation of the North Atlantic and European region. Copyright (c) 2012 Royal Meteorological Society
\end{abstract}

Key Words: North Atlantic SST errors; coupled models; storm tracks

Received 7 September 2011; Revised 23 January 2012; Accepted 1 February 2012; Published online in Wiley Online Library

Citation: Keeley SPE, Sutton RT, Shaffrey LC. 2012. The impact of North Atlantic sea surface temperature errors on the simulation of North Atlantic European region climate. Q. J. R. Meteorol. Soc. DOI:10.1002/qj.1912

\section{Introduction}

In the most recent assessment of state-of-the-art climate models, the fourth integrated assessment report of the Intergovernmental Panel on Climate Change (IPCC AR4), many of the models showed a common cold bias in the North Atlantic sea surface temperature (SST) (see Figure 8.2 and supplementary Figure 8.1(b) of WG1 report of AR4 (Randall et al., 2007)). This error is a cold bias in the region south of Greenland at around $45^{\circ} \mathrm{N}$. In fact, the bias in the North Atlantic is one of largest errors in the SST in the multimodel ensemble mean. The root mean square error for all the models was found to be between 4 and $5{ }^{\circ} \mathrm{C}$ in the North Atlantic Current region, compared to 1-2 ${ }^{\circ} \mathrm{C}$ in most of the global ocean. The mean bias can be much larger in the winter months. Often this cold bias is accompanied by a warm bias close to the North American coast. These biases are largely due to the poor representation of the Gulf Stream and North Atlantic Current in the models (e.g. Willebrand et al., 2001; Eden et al., 2004). The Gulf Stream separates too far north from the coast of the USA and the North Atlantic Current flow tends to be too zonal; instead of turning northward at the Grand Banks of Newfoundland it turns northward near the mid-Atlantic ridge region. These biases, though relatively small in spatial scale, provide heating anomalies that have the potential to 
induce a large-scale atmospheric response (e.g. Hoskins and Karoly, 1981; Kushnir et al., 2002) and change the local SST gradients in a region that has been shown to have an impact on the atmospheric storm tracks (Brayshaw et al., 2011), and therefore have the potential to have a significant impact on the atmospheric circulation downstream. Recent work by Balmaseda et al. (2010) has shown that anomalies in this region strongly affect the summer mean circulation over Europe.

Previous studies have shown that when ocean models are run at high resolution $\left(\sim \frac{1}{10}^{\circ}\right)$, the representation of the path of the Gulf Stream and the North Atlantic Current is much improved (e.g. Smith et al., 2000; Bryan et al., 2007). As most current state-of-the-art climate models cannot accurately represent the path of the Gulf Stream and North Atlantic Current in the North Atlantic, the question that motivates this study is: "What impact does the SST error, induced by poor representation of the Gulf Stream and North Atlantic Current in low-resolution climate models, have on the climate of the North Atlantic and European regions?'

A previous study that has looked at the impact on the atmosphere by improving the ocean model representation of the Gulf Stream and North Atlantic Current is by Weese and Bryan (2006). They improved the representation of the Gulf Stream in the CCSM3 ocean model. However, when the improved ocean model was coupled to the atmosphere there were still large SST biases in the coupled model (of the order of $8{ }^{\circ} \mathrm{C}$ in the North Atlantic). By reducing the SST bias by $\sim 2{ }^{\circ} \mathrm{C}$ in the coupled model the impact was to reduce the model mean sea-level pressure biases over the polar regions $(\sim 2 \mathrm{hPa})$ and the Azores high $(0.5-1.5 \mathrm{hPa})$, but biases of $\sim 3 \mathrm{hPa}$ remained. This suggests there is the potential for the SST biases to explain the large-scale circulation biases in a coupled model.

In this study, rather than try to directly correct the model's representation of the Gulf Stream and North Atlantic Current, we instead consider the impact of the SST bias on the atmospheric component of the model. This allows us to estimate the atmospheric response to the SST bias and the improvement that may be gained if it were substantially reduced. Our hypothesis is that the local SST bias in the North Atlantic, although small in spatial scale, can explain a substantial part of the biases we see in the large-scale atmospheric circulation over the North Atlantic and European region.

The outline of the paper is as follows: in section 2 we present a description of the model used, the biases in the mean atmospheric state of the coupled model compared to reanalysis data, and the experimental methodology; section 3 shows the results from our atmosphere-only experiments with and without the North Atlantic SST bias, and discusses the impact on the mean state and the variability of the North Atlantic; and the conclusions are presented in section 4.

\section{Model description and experimental methodology}

HiGEM is a high-resolution coupled atmosphere-ocean model that has been developed for climate simulations. The model is a higher horizontal resolution version of the UK Met Office Unified Model HadGEM1.2 and is described in detail by Shaffrey et al. (2009). The atmospheric component of the model, HiGAM, has a longitude-latitude grid of $0.833^{\circ} \times 1.25^{\circ}$ and 38 levels in the vertical with a model top at $39 \mathrm{~km}$. The ocean model has a $\frac{1}{3}^{\circ} \times \frac{1}{3}^{\circ}$ ocean resolution and 40 unevenly spaced levels in the vertical, with greater resolution near the surface $(\sim 10 \mathrm{~m})$, decreasing smoothly to a resolution of $300 \mathrm{~m}$ at depth. At a resolution of a $\frac{1}{3}^{\circ} \times \frac{1}{3}^{\circ}$ the ocean model is eddy permitting but does not fully resolve eddy processes. As noted in Smith et al. (2000), the resolution of the ocean must be greater to fully resolve baroclinic eddies. However, long integrations of coupled climate models that fully resolve eddy processes are not possible with the computing resources currently available.

\subsection{Coupled model mean state biases}

The coupled model has previously been described in detail in Shaffrey et al. (2009). Here we focus on the North Atlantic winter and present a brief summary of biases in the winter mean compared to ERA-40 (Uppala et al., 2005) for a few key atmospheric variables. All differences presented in Figure 1 are for model mean fields averaged over 50 winters (defined for the rest of the paper as December, January and February) minus a reanalysis mean field averaged over 45 winters, except for the SST biases, which are relative to the Atmospheric Model Intercomparison Project (AMIP) II (Hurrell et al., 2008) SST fields.

Figure1(a) shows that the HiGEM coupled model also displays the large bias in the North Atlantic SST found in the IPCC AR4 models. In winter, the SST bias is over $8 \mathrm{~K}$ too cold in the mid North Atlantic, and $6 \mathrm{~K}$ too warm near the coast of North America. As highlighted in the Introduction, this is because of errors in the representation of the northward path of the warm waters in the Gulf Stream and North Atlantic Current.

Figure1(b) shows the bias in the winter average mean sea-level pressure (MSLP), over the North Atlantic. There is a dipole bias pattern with a low-pressure centre over Iceland $(2 \mathrm{hPa})$ and a high-pressure centre over the Azores ( $4 \mathrm{hPa}$ ). The MSLP bias over the North Atlantic resembles the spatial pattern of the dominant mode of atmospheric variability in the region, the North Atlantic Oscillation (NAO) (e.g. Wallace and Gutzler, 1981). There is also a high-pressure bias of over $4 \mathrm{hPa}$ that extends over Siberia and a large proportion of the Arctic. The bias can also be seen in the zonal winds at $850 \mathrm{hPa}$ in Figure 1(d), with the westerlies being too strong $\left(\sim 2 \mathrm{~m} \mathrm{~s}^{-1}\right)$ in the North Atlantic and over the UK and into northwestern Europe, consistent with geostrophic balance. The easterlies in the Subtropics are also found to be too strong $\left(\sim 2 \mathrm{~m} \mathrm{~s}^{-1}\right)$. Over the North Atlantic region the bias is equivalent barotropic, with the bias in the mid troposphere similar to that seen at the surface, with a dipole in the geopotential height at $500 \mathrm{hPa}$ (Z500) (Figure 1(c)). There is a bias of over $20 \mathrm{~m}$ for both centres of action of the dipole.

\subsection{Experimental set-up}

To investigate the impact of the large SST bias in the North Atlantic on atmospheric circulation in the coupled model we use the atmosphere-only version of HiGEM, which we will refer to as HiGAM. Experiments were carried out for winter only. Two model integrations were run: the control run and the perturbed run. In the control run HiGAM is forced with observed SSTs and sea ice concentrations taken from AMIP II. In the perturbed run HiGAM is forced with observed SSTs with the winter mean SST bias superimposed in the 
(a)

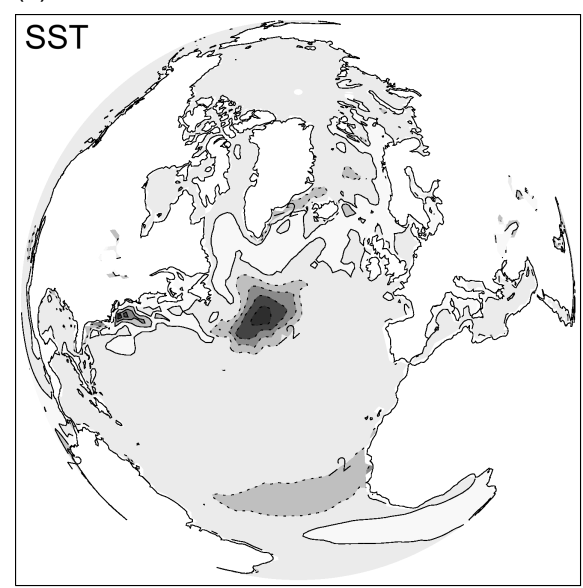

(c)

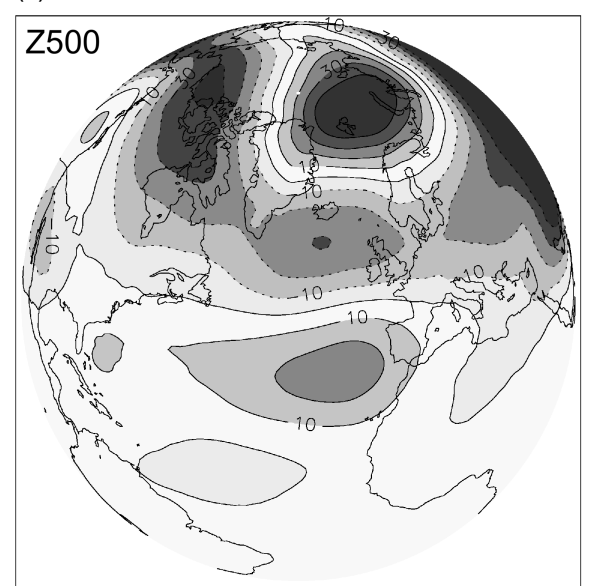

(b)

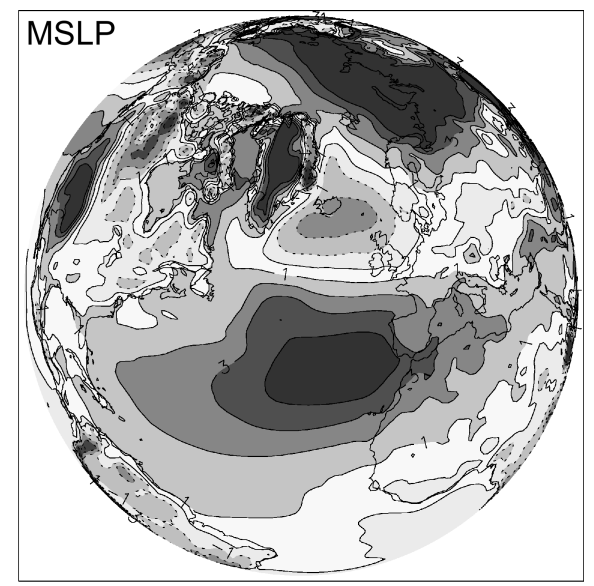

(d)

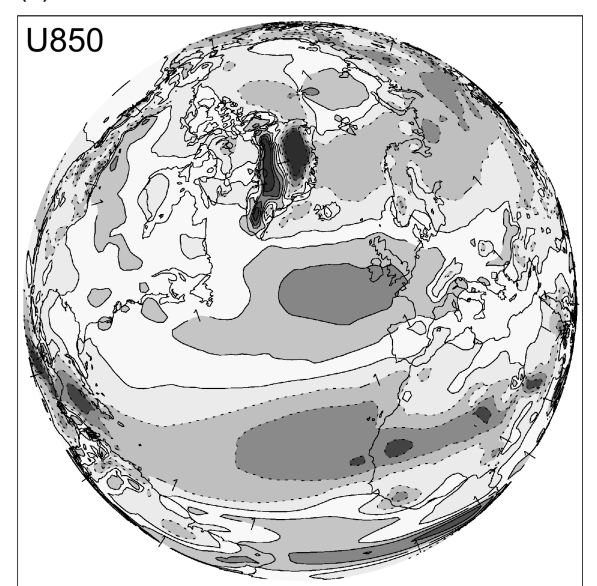

Figure 1. Difference between winter (DJF) means for a 50-year HiGEM model run and observed climatology. (a) SST differences between HiGEM and AMIPII SSTs for the period 1980-2001. Contour interval 2 K. (b) Mean sea-level pressure differences between HiGEM and ERA-40 (1957-2002). Contour interval $1 \mathrm{hPa}$. (c) $500 \mathrm{hPa}$ geopotential height (Z500) differences between HiGEM and ERA-40 (1957-2002). Contour interval 10 m. (d) Zonal wind at $850 \mathrm{hPa}$ (U850) differences between HiGEM and ERA-40 (1957-2002). Contour interval $1 \mathrm{~m} \mathrm{~s}^{-1}$. Negative contours are dashed. This figure is available in colour online at wileyonlinelibrary.com/journal/qj

North Atlantic. We found that the HiGEM SST bias pattern in the North Atlantic was approximately constant over the winter period and therefore used the winter mean model bias. The mean winter bias is shown in Figure 1(a). We used a mask for the perturbation so that it was only applied to the North Atlantic region. To reduce edge effects the perturbation was smoothed linearly over $8^{\circ}$ of latitude over the southern boundary at $28.33^{\circ} \mathrm{N}$. This was not possible for the northern boundary because of the presence of land masses and sea ice, so we used the zero contour in the SST bias as the edge of the perturbation. The edges of the boundary for the east and west have been set by the basin edges. Within the given boundaries the perturbation is only applied to permanently ice-free regions. This avoids putting an anomalous SST field where sea ice was prescribed by the AMIP II data. (The perturbation used for the experiments is shown in Figure 5(a)).

The effect the SST biases have on the absolute SST field in winter can be seen in Figure 2. This shows the winter mean for the AMIP II SSTs (Figure 2(a)) and then for the AMIP II SSTs with the coupled model bias applied (Figure 2(b)). It can be seen that applying the perturbation changes the location of the maximum SST gradient within the basin.

The control integration is an AMIP II run of HiGAM. In this study we analyse the 19 winters from 1983 to 2001.
The perturbed integrations with the model SST bias added to the observed SSTs are run for each winter for 6 months from 1 September initial conditions, taken from the control integration. Each 6-month integration includes 'spin-up' time from September to November. We analyse results for the winter period (DJF).

\section{Results and discussion}

To identify the impact of the SST bias in the North Atlantic we compare the perturbed and control experiments. We first consider the impact that perturbing the SST has on the surface fluxes to determine the impact on the thermodynamics of the system in section 3.1. Having shown that the SST perturbation produces a large local heat flux perturbation to the atmosphere we present in section 3.2 the differences in winter mean atmospheric state for the same atmospheric fields presented in Figure 1. Finally, in section 3.3 we present the differences in the model winter variability.

\subsection{Impact of the SST perturbation on surface fluxes}

Any SST perturbation will influence the atmosphere by altering the surface fluxes. As noted in earlier studies 
(a)

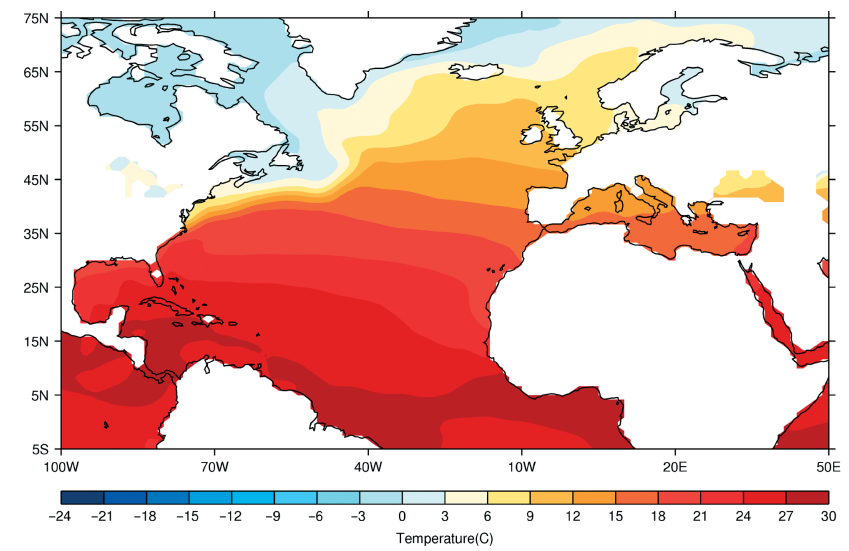

(b)

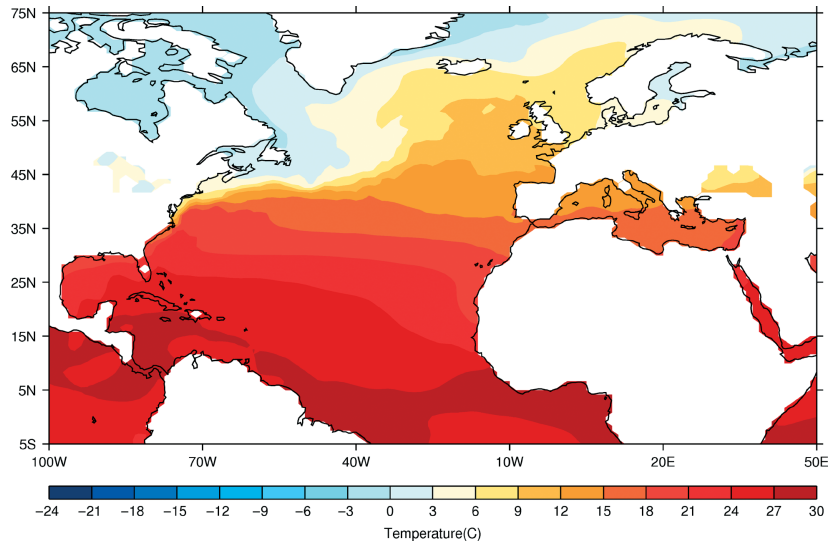

Figure 2. Mean SSTs $\left({ }^{\circ} \mathrm{C}\right)$ for winter (DJF) applied to atmospheric model for the control run (a) and the perturbed run (b).

(a)

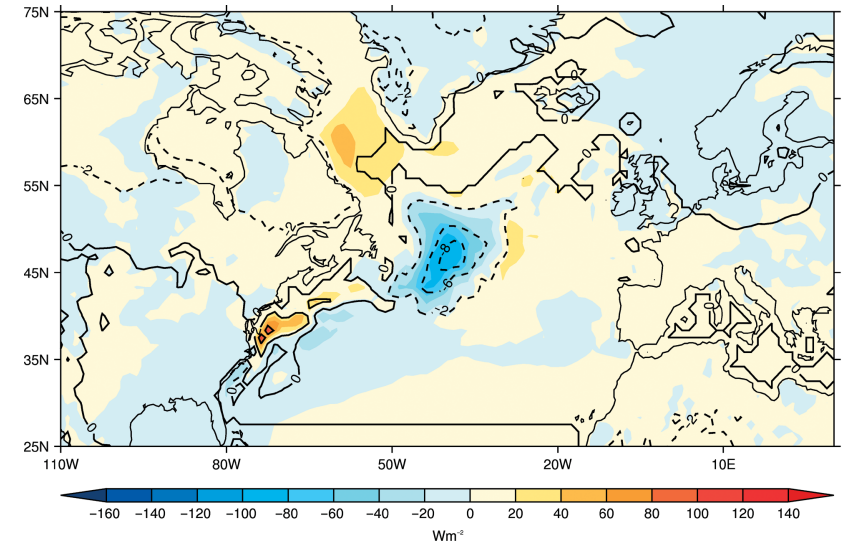

(b)

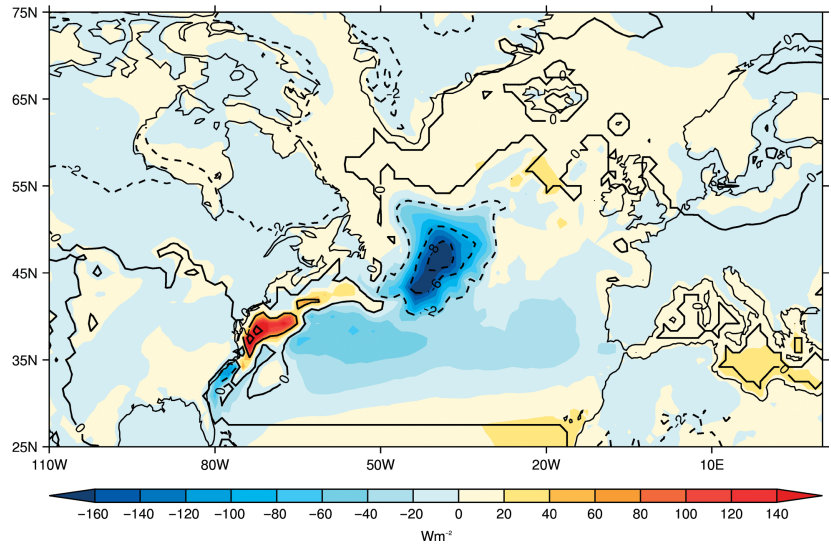

Figure 3. Difference in mean surface (a) sensible heat flux and (b) latent heat flux between perturbed and control runs for the atmosphere-only runs. Colours show the heat flux perturbation, positive values indicate increased flux into the atmosphere, with a contour interval of $20 \mathrm{~W} \mathrm{~m}^{-2}$. SST perturbations are shown in the line contours, which are irregularly spaced and have values $-8 \mathrm{~K},-6 \mathrm{~K},-2 \mathrm{~K}, 0 \mathrm{~K}, 2 \mathrm{~K}, 6 \mathrm{~K}$.

(Frankignoul, 1985; Kushnir and Held, 1996) the relationship between an SST perturbation and the subsequent heating in the atmosphere can be complex. To investigate the impact the SST perturbation has on the local and largescale atmospheric circulation we first consider the changes in atmospheric heating via surface fluxes and latent heating.
Figure 3 shows the surface sensible heat flux and latent heat flux differences between the perturbed and control runs of the SST perturbation experiment. There are positive surface heat fluxes into the atmosphere over the warm SST perturbation and negative fluxes where the SST is colder. Our results are similar to previous general circulation model (a)

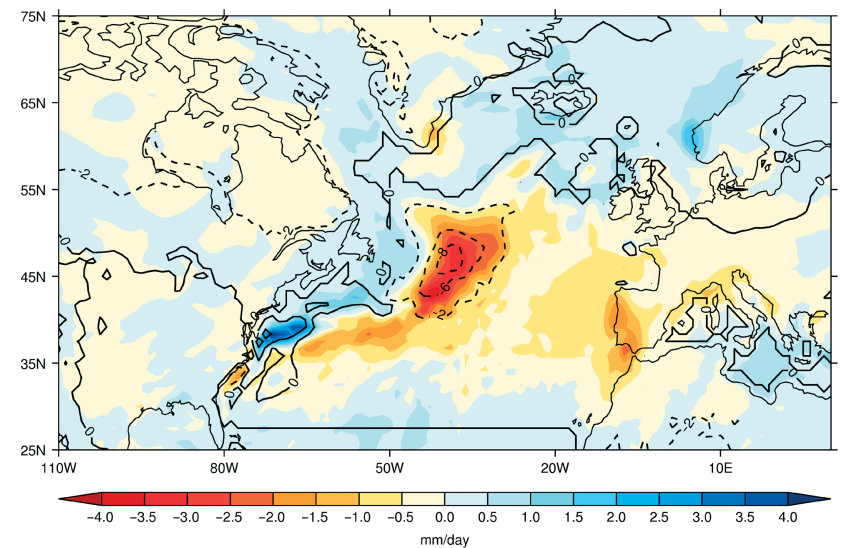

(b)

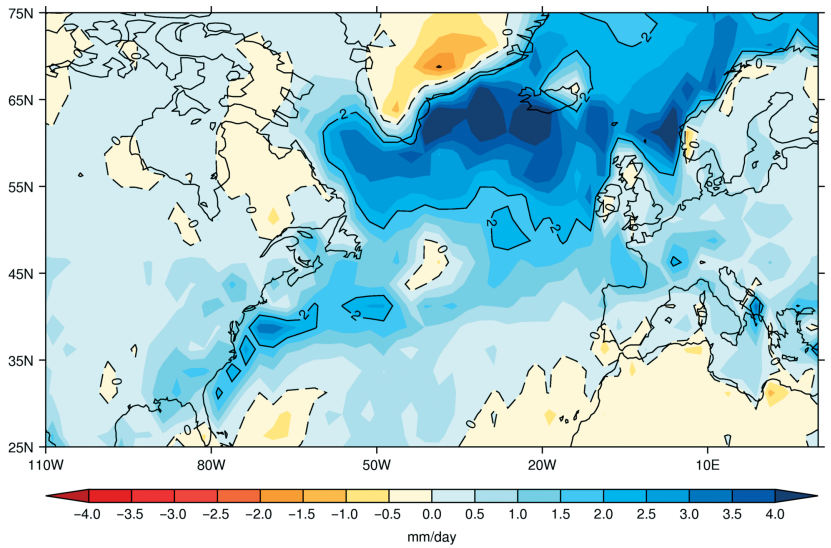

Figure 4. (a) Difference in precipitation between perturbed and control runs for the atmosphere-only runs. Colour interval is 0.5 mm per day and overlaid contours are the SST perturbation. SST perturbations are shown in the line contours, which are irregularly spaced and have values $-8 \mathrm{~K}$, $-6 \mathrm{~K},-2 \mathrm{~K}, 0 \mathrm{~K}, 2 \mathrm{~K}, 6 \mathrm{~K}$. (b) Winter precipitation bias in the coupled model when compared to observations (December 1979-February 2005) (HiGEM-CMAP). 
experiments (e.g. Kushnir and Held, 1996); the heat flux response is co-located with the SST perturbation, with a very slight shift upstream (west) of the perturbation; this is more apparent for the large cold anomaly. As well as seeing a sensible heat flux response co-located with the anomalies we also note a change over the Labrador Sea region. This is due to the advection of cold air from the north (circulation changes are shown in Figure 5) over a sea-ice-covered region and hence we do not see the same response in the latent heat flux.

The surface sensible heat flux associated with the SST change is approximately $10 \mathrm{~W} \mathrm{~m}^{-2} \mathrm{~K}^{-1}$ for both the cold and warm anomalies, with the response over the warm anomaly being slightly larger. The response seen in the latent heat fluxes is approximately double the sensible heat flux, with approximately $20 \mathrm{~W} \mathrm{~m}^{-2} \mathrm{~K}^{-1}$. This means that the total turbulent (sensible plus latent) heat fluxes per $1 \mathrm{~K}$ SST perturbation are approximately $30 \mathrm{~W} \mathrm{~m}^{-2}$. This would act to damp the SST anomaly if the ocean were allowed to respond. These results are consistent with the theoretical values suggested by Large and Danabasoglu (2006) for surface fluxes and SST perturbations $\left(30 \mathrm{~W} \mathrm{~m}^{-2} \mathrm{~K}^{-1}\right)$.

To determine how much of the latent heating at the surface is released in the local atmospheric column as condensational heating, we consider the local precipitation changes. The impact of the SST perturbation on the precipitation is shown in Figure 4(a). The precipitation response is closely tied to the SST perturbation: precipitation amounts are reduced where the SST perturbation is negative and enhanced where the SST perturbation is positive. The negative precipitation anomaly accounts for approximately half of the local changes in evaporation due to the SST perturbation, i.e. $50 \%$ of the excess moisture is condensed locally, releasing latent heat. This is similar to the result of Kushnir and Held (1996), who found that about 50\% of the surface latent heat flux was realized as local latent heating due to condensation and the rest is transported out of the region.

The biases in the coupled model precipitation compared to CMAP climatology (Xie and Arkin, 1997) are shown in Figure 4(b). There is a large precipitation bias north of $55^{\circ} \mathrm{N}$ of over $3 \mathrm{~mm}$ per day. Both the perturbed and control experiments have a similar precipitation bias relative to CMAP climatology, hence the small differences in this region in Figure 4(a). This shows that SST biases in the North Atlantic are not the main cause of the precipitation differences north of $55^{\circ} \mathrm{N}$. Figure 4 (b) does, however, have similarities to Figure $4(\mathrm{a})$. There is a reduction in precipitation over the central North Atlantic, where the coupled model has a cold SST bias relative to observations and there is an increase in precipitation over the warm SST bias off the coast of North America. The HiGEM biases are not as strong as the precipitation difference produced in the perturbed atmospheric model experiments, which suggests other processes within the model are also important. The large bias over the subpolar gyre region is not explained by the SST bias in the North Atlantic.

\subsection{Mean state}

Having shown the impact of SST perturbation on surface fluxes we go on to examine the response of local and large-scale mean atmospheric circulation.
The impact of SST perturbation (Figure 5(a)) on the MSLP field is shown in Figure 5(b). Figure 5 shows that SST perturbation is not just having a local influence on the atmospheric circulation but is impacting the large-scale downstream flow. The response is a dipole in pressure over the North Atlantic with a low-pressure centre just north of Iceland of magnitude $\sim 3 \mathrm{hPa}$ and a high-pressure centre of over $4 \mathrm{hPa}$ slightly to the north of the Azores. There is also a significant impact further downstream, with a highpressure anomaly of $\sim 4 \mathrm{hPa}$ over Siberia. Comparing this to Figure 1(b) we find that the imposed SST perturbation produces a very similar MSLP dipole response to that of the coupled model MSLP bias. The response in our HiGAM experiment is of similar magnitude over the North Atlantic region for the positive centre of the dipole, and slightly stronger $(\sim 1 \mathrm{hPa})$ for the negative centre. This suggests that the SST biases in the coupled model play an important role in explaining the MSLP bias seen in the model. It should be noted that even though we only have a relatively small sample size in these experiments (19 winters) the results are significant above the $95 \%$ level for the fields shown in Figure 5. The significance threshold changes locally but, as a general guide for the response, any change for MSLP of $\pm 2.5 \mathrm{hPa}$ and U850 $\pm 2 \mathrm{~m} \mathrm{~s}^{-1}$ are significant at at least the 95\% level. The Z500 response is only significant at the $90 \%$ level in the regions of negative height changes, which is not too surprising given the fact that the anomaly is applied at the surface and the sample size is relatively small.

Despite the striking similarity between Figures 1(b) and 5(b) it is important to note the differences as well. The positive pressure bias over the southwest USA present in HiGEM is not found in the HiGAM response. The pressure response over Siberia is $\sim 3 \mathrm{hPa}$ weaker in magnitude in HiGAM than the HiGEM model bias. The positive pressure anomaly over Siberia in HIGAM does not extend over the Arctic ocean as it does in HiGEM (Figure 1(b)) and the HiGAM pressure response over the Arctic is negative. This suggests that not all of the HiGEM MSLP error over Siberia can be explained by a downstream response to the North Atlantic SST errors. Finally, overall the HiGAM response pattern in MSLP in the North Atlantic is shifted 5-10 northwards. We will discuss the potential causes of these differences at the end of the section.

Given the surface pressure differences shown in Figure 5(b) we would expect through geostrophic balance that there would be anomalously strong westerlies at mid latitudes in the mean state differences between the perturbed and control HiGAM experiments. The response of the zonal winds at $850 \mathrm{hPa}$ to the SST perturbation in HiGAM is shown in Figure 5(d). The results are of similar pattern and magnitude to the coupled model biases within the North Atlantic basin and western Europe (Figure 1(d)), except for a northward shift, which is consistent with the shift in the MSLP pattern.

The response in the mid troposphere is shown in Figure 5(c). The change in geopotential is a reduction in height over the polar regions and an increase in height over the Atlantic in the mid latitudes. The magnitude and pattern of the coupled model biases at $500 \mathrm{hPa}$ are broadly similar to the differences between the perturbed and control runs. The results from the surface and the mid troposphere suggest that the response to the SST perturbation is approximately barotropic. This can be seen more clearly in the longitude-height cross-sections shown in Figure 6. The 
(a)

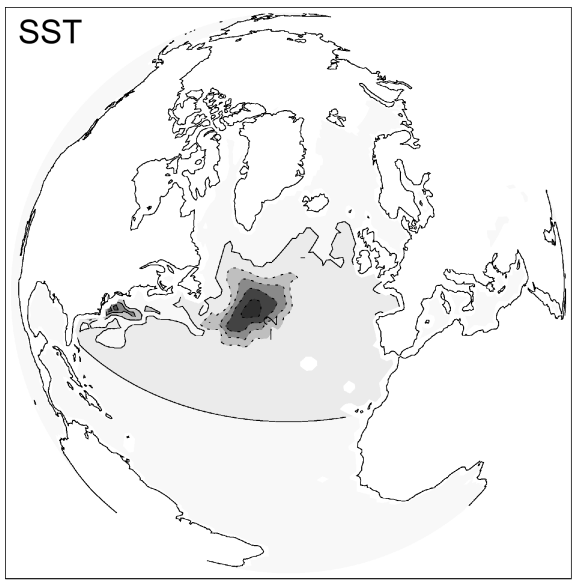

(c)

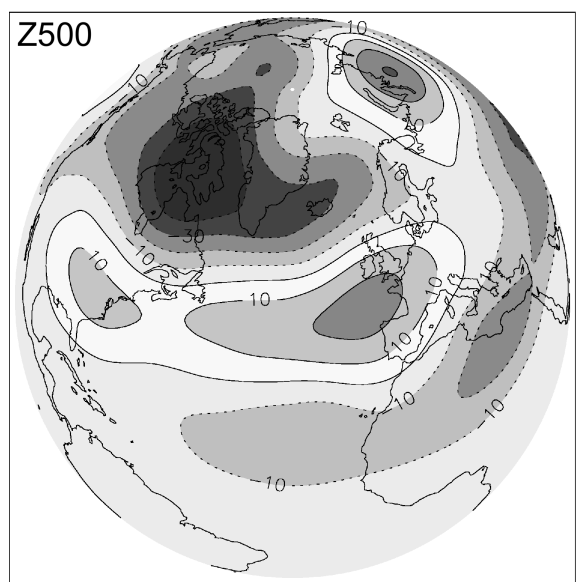

(b)

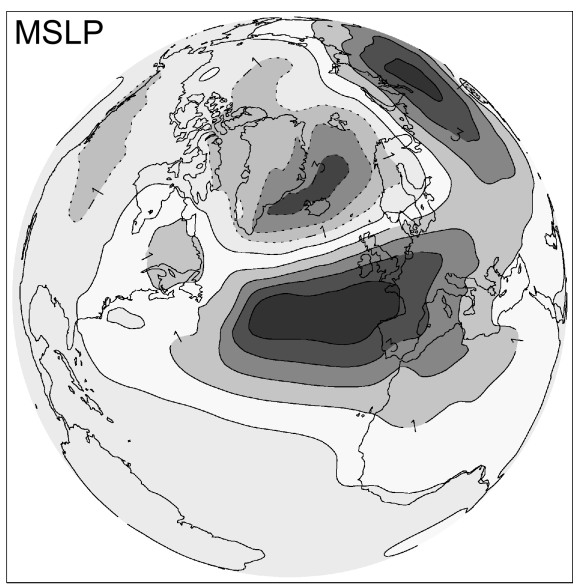

(d)

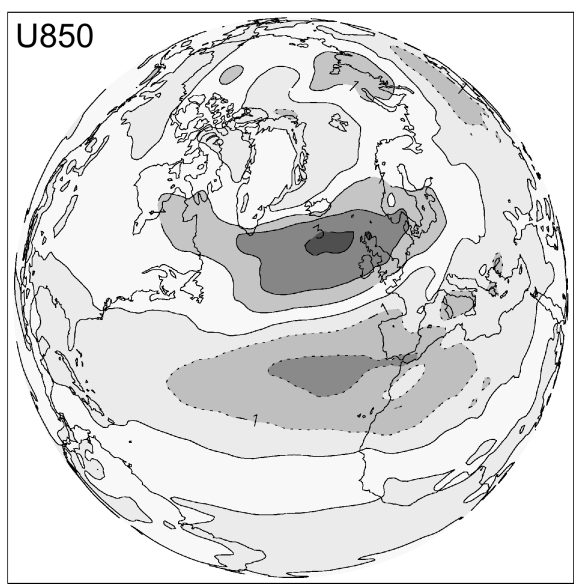

Figure 5. (a) shows SST perturbation applied to all months of the model integration based on the coupled model bias from 50 years of coupled model integration of HiGEM. (b),(c) and (d) as in Figure 1 but for differences between mean 19 winter state for the perturbation and control atmosphere-only runs. This figure is available in colour online at wileyonlinelibrary.com/journal/qj

(a)

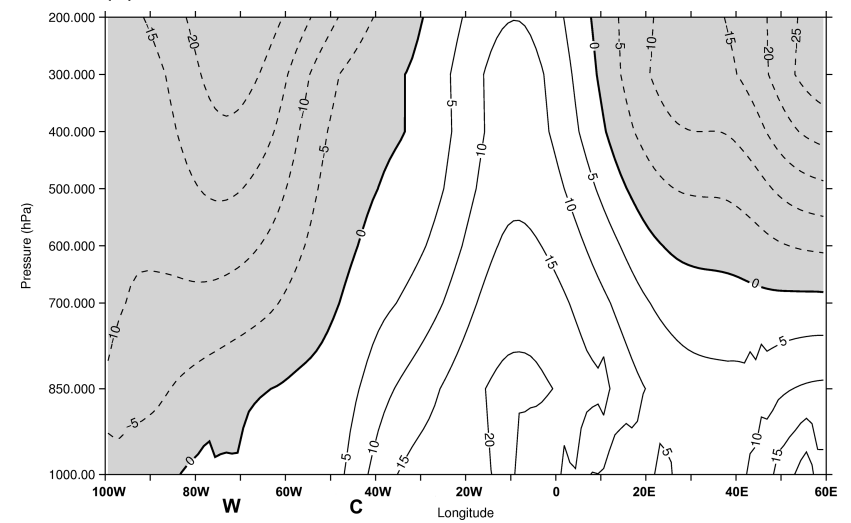

(b)

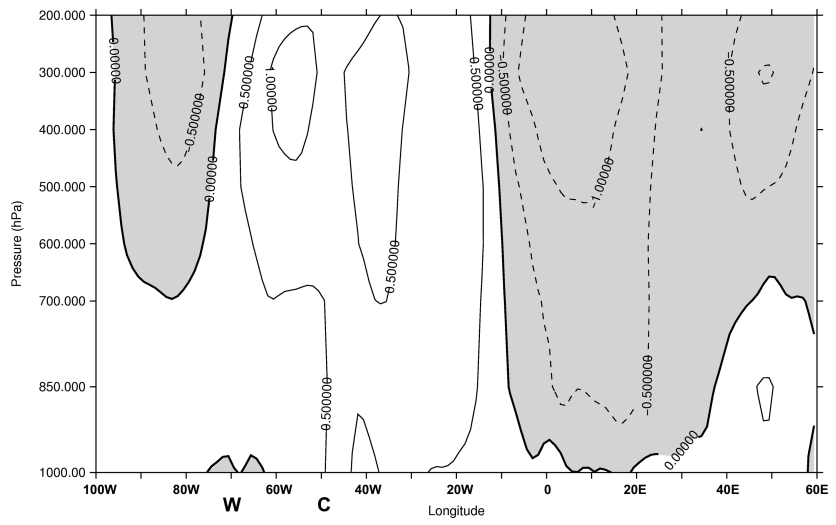

Figure 6. Geopotential height differences (a) and meridional wind differences (b) for $100^{\circ} \mathrm{W}-60^{\circ} \mathrm{E}$ averaged over the latitudes $40-60^{\circ} \mathrm{N}$. The longitudinal location of SST perturbation is marked with a ' $\mathrm{W}^{\prime}$ ' for the centre of the warm anomaly $\left(39^{\circ} \mathrm{N}\right)$ and ' $\mathrm{C}$ ' for the centre of the cold anomaly $\left(48^{\circ} \mathrm{N}\right)$.

figure shows the average geopotential height and meridional wind for the latitude band $40-60^{\circ} \mathrm{N}$ (encompassing the latitudes over which the cold SST perturbation is applied $\left.\left(45-55^{\circ} \mathrm{N}\right)\right)$. The longitudes of the centres of the warm $(\mathrm{W})$ and cold (C) SST perturbations are marked.

At the surface the response is somewhat similar to what we might expect from the linear response studied by Hoskins and Karoly (1981). Hoskins and Karoly (1981) used a linear stationary wave model and found that the linear response to a mid-latitude heating anomaly was balanced by meridional flow drawing colder air from the pole, producing a low-pressure anomaly to the east of the heating perturbation. As discussed in the review paper of Kushnir et al. (2002), many studies show that a linear response to a heating anomaly can be strongly modified by eddy feedbacks, leading to a barotropic response to the perturbation. It was also shown that the details of the response are sensitive to the background state of the 
model, in particular where the heating is in relation to the westerly jet stream. In the Gulf Stream separation region the response to the warm SST anomaly is baroclinic; the geopotential height at $500 \mathrm{hPa}$ (Figure 5(c)) is of opposite sign to that of the MSLP, but the changes in circulation at the surface and in the mid troposphere in HiGAM are not substantial. The warm SST anomaly may still be important for the overall response and will be discussed later. The response over the cold SST perturbation is significant. In the North Atlantic Current region the reduction in surface heat fluxes into the atmosphere, because of the cold SST perturbation, is balanced by meridional flow of warmer air from the south (Figure 6(b)) and a high-pressure anomaly to the east (Figure 6(a)). The response aloft is not consistent with the linear response of Hoskins and Karoly; instead of a baroclinic response our results show the response is closer to equivalent barotropic. The cold anomaly is within the storm track region (shown and discussed in section 3.3) and the effect of the transient eddies leads to an equivalent barotropic response in this region with a surface high pressure and positive geopotential height. This suggests that in this model the eddies are playing a key role in the atmospheric response to the SST perturbations. There is a downstream barotropic response in the atmosphere because of the eddies modifying the baroclinic response to the SST perturbations. The coupled model bias in Figure 1 also displays a barotropic pattern over the North Atlantic, with the biases at $500 \mathrm{hPa}$ and at the surface being co-located.

Comparison of the coupled model bias (Figure 1) with the difference between the perturbed and control runs (Figure 5) shows that the SST bias in the North Atlantic causes a large-scale response in the North Atlantic and downstream into Eurasia. There is a northward shift in the response in the atmosphere-only model experiments compared to the coupled model bias. The northward shift of the response pattern could be caused by many different and interacting factors and to some extent may be expected; Kushnir et al. (2002) note in their review paper that the large-scale response to an SST anomaly can be sensitively dependent on the background state of the model and also the location of the storm track relative to the anomaly. The climatologies of HiGAM and HiGEM, are not identical. For example, the intertropical convergence zone is slightly further north in the atmosphere-only model and there will be differences in sea ice edge in the coupled model, which will have a large impact on heat fluxes from the ocean to the atmosphere in winter. Another element of analysis is that we have only considered the North Atlantic SST biases found in HiGEM and there are also biases in other parts of the ocean and atmosphere that may play a role. One element is the local heating bias caused by the large precipitation bias over the North Atlantic subpolar gyre region in the model (shown in Figure 4). Finally, there are also coupled feedbacks between the atmosphere and ocean in HiGEM that are not represented in our experiments.

In summary, the differences between the HiGAM perturbed and control experiments show that the perturbations to the SST in the Gulf Stream and the North Atlantic Current region lead to local surface heat flux changes and changes in precipitation. The anomalous heat fluxes produce a circulation response of similar pattern and magnitude to those seen in the coupled model mean winter state biases compared to observations. The response is not confined to the vicinity of the SST anomaly and there is a wave-like response in the mid troposphere, extending over the pole and Siberia, with a small impact on the North Pacific region. This suggests that an important way of improving the model mean state for the North Atlantic/European region would be to have better representation of the Gulf Stream and North Atlantic Current.

\subsection{Variability}

In the previous section we have shown that the North Atlantic SST biases in the coupled model contribute to the time-mean atmospheric biases we see in the North Atlantic. We now go on to show the impact of SST bias on the variability of the model atmosphere.

First, we consider the impact of SST anomalies on the synoptic-scale variability in the North Atlantic region. We diagnose the storm track by calculating the variance of 2 - to 6-day band-pass Lanczos-filtered (Duchon, 1979) 6-hourly MSLP data for each winter. Figure 7(a) shows the storm track (MSLP variance) in reanalysis data (ERA-40) and, as noted in many previous studies, the track has a 'southwestnortheast' tilt, with the maximum variance centred on the western side of the Atlantic. Comparing the reanalysis data with the coupled model (Figures 7(a) and (b), we see that in HiGEM the storm tack is in a similar location, but the peak of the MSLP variance extends further west and has a greater maximum value ( $65 \mathrm{hPa}^{2}$ compared to $55 \mathrm{hPa}^{2}$ in ERA-40).

The same change in storm track behaviour is seen when we compare the control and perturbed model integrations (Figures 7(c) and (d) respectively). When the coupled model bias is included, the storm track is more vigorous and extends further westward across the basin. It should also be noted that the perturbed run shows a greater 'southwest-northeast' tilt in the storm track than is found in the control integration, which is slightly closer to the orientation of the storm track in HiGEM and in observations. As noted in the previous section, the storm track response is consistent with the barotropic large-scale response we find in the mean state differences.

The difference in storm track activity is shown in Figures 8(a) and (b) for the difference between the perturbed and control HiGAM runs and HiGEM coupled model bias respectively. In both cases the activity is intensified near the coast, where baroclinicity is increased due to the warm SST anomaly increasing the surface temperature gradient at the coastline (see Figure 2). The maximum change in SST gradient is at approximately $45^{\circ} \mathrm{N}$ (not shown) and the maximum MSLP variance is located at a latitude $5-10^{\circ}$ further north, consistent with Brayshaw et al. (2008), who looked at the storm track response to SST. The peak of activity is located off the coast of Newfoundland. The increase in storm activity does not continue downstream across the whole of the North Atlantic basin. This may be because of the presence of the cold anomaly, which reduces the moisture availability in the region and also weakens the SST gradient within the region of $50-58^{\circ} \mathrm{N}$ and $43-20^{\circ} \mathrm{W}$ (not shown). This will act to inhibit the deepening of storms in this region and reduce the MSLP variance. The difference between the HiGAM experiments (Figure 8(a)) is larger than the bias in HiGEM (Figure 8(b)), which might be because the coupled feedbacks are not present in HiGAM. Interestingly, it appears from these results that the warm SST anomaly may be the most important part of the North Atlantic SST perturbation for the storm track response. 
(a)

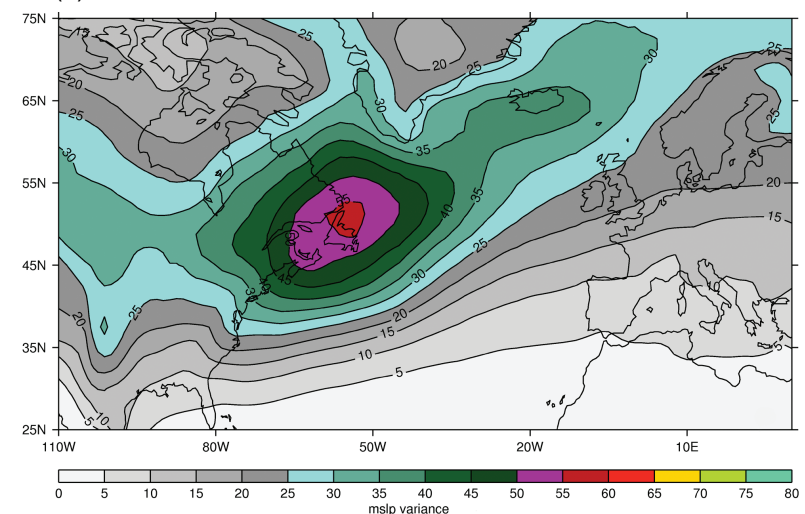

(c)

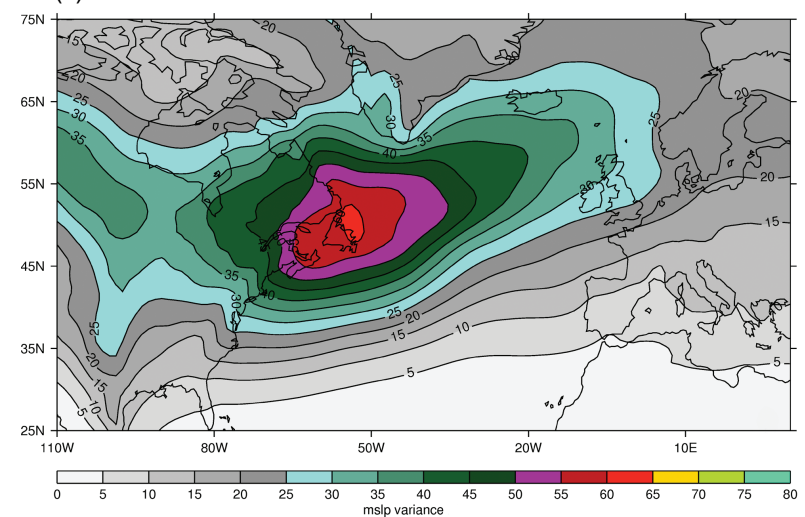

(b)

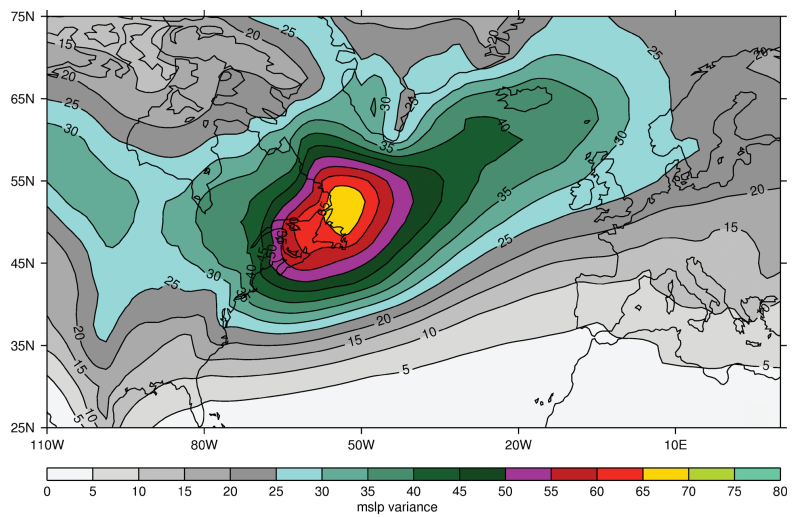

(d)

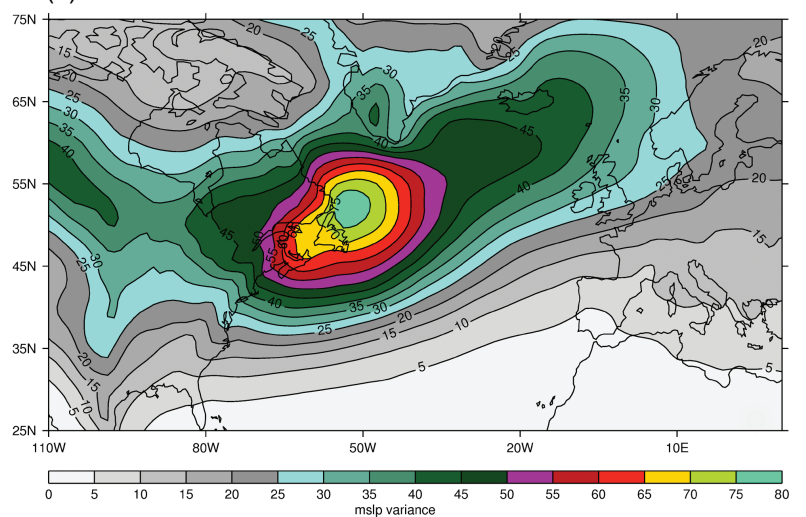

Figure 7. Variance of bandpass 2- to 6-day filtered winter (DJF) MSLP fields for (a) ERA40; (b) HiGEM; (c) HiGAM control and (d) HiGAM perturbed. Units in $\mathrm{hPa}^{2}$.
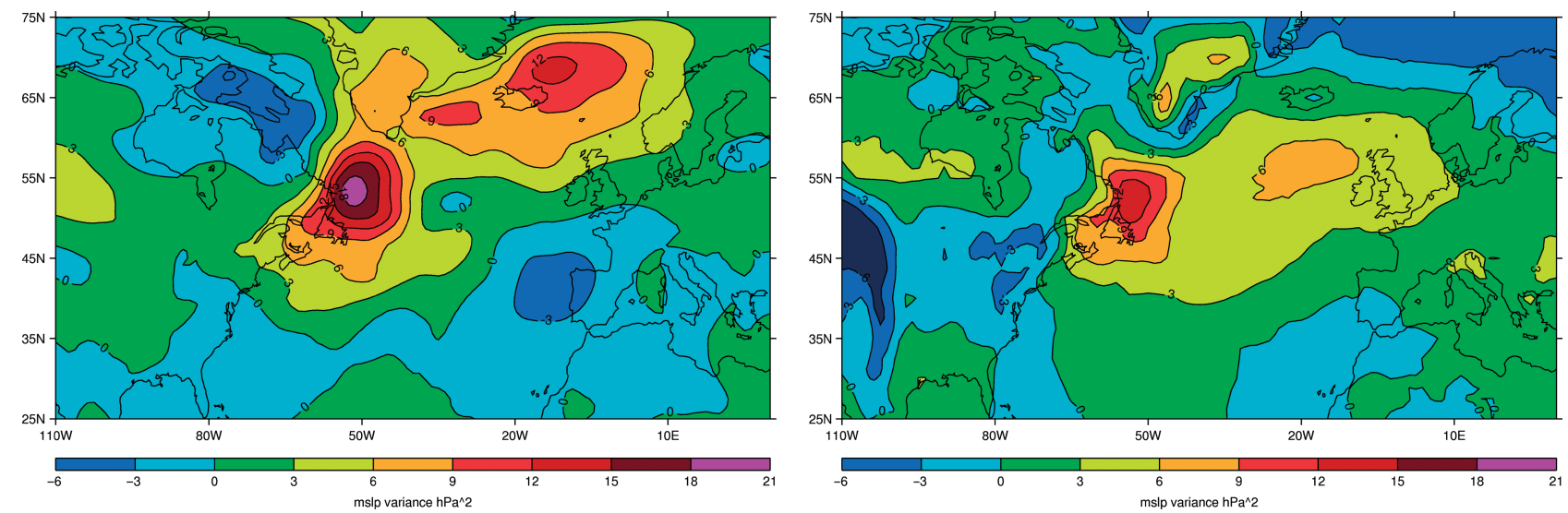

Figure 8. Differences in the variance of bandpass 2- to 6-day filtered winter (DJF) MSLP fields for the HiGAM experiments (left) and the HiGEM coupled model bias (right). Units in $\mathrm{hPa}^{2}$.

Considering the winter mean barotropic response presented in the results above and the storm track response shown here suggests first that the eddies dominate the storm track response and secondly that both parts of the SST perturbation in the North Atlantic play a role, even though the warm bias is far smaller in spatial extent than the cold bias in the mid North Atlantic.

To assess the impact of the North Atlantic SST bias on the coupled model's representation of the natural variability, we consider the spatial pattern of the leading mode of variability for the region, the North Atlantic Oscillation (NAO). In this case we define the $\mathrm{NAO}$ as the leading mode of variability (EOF1) using principal component analysis of MSLP for the Atlantic region $\left(90^{\circ} \mathrm{W}-45^{\circ} \mathrm{E}, 20-90^{\circ} \mathrm{N}\right)$. We have calculated the EOF1 using monthly mean MSLP anomalies for December, January and February for each of the winters. EOF1 is shown in Figure 9 for ERA40 (45 winters), HiGEM (50 winters), and the HiGAM (atmosphere-only) integrations (19 winters) for the control and perturbed runs respectively. Comparing Figures 9(a) and (b), the low-pressure centres over Iceland are similar between ERA-40 and HiGEM. There are large differences between the high-pressure lobes of the dipole. In ERA-40 the high-pressure lobe has a larger magnitude and is located over the Azores region. In HiGEM the high-pressure centre is slightly weaker (by about $100 \mathrm{~Pa}$ ), spread over a larger area and located further east over continental Europe.

Although the NAO is considered to be an atmospheric mode of variability, it has the potential on seasonal timescales to be modulated by the ocean (e.g. Rodwell and 
(a)

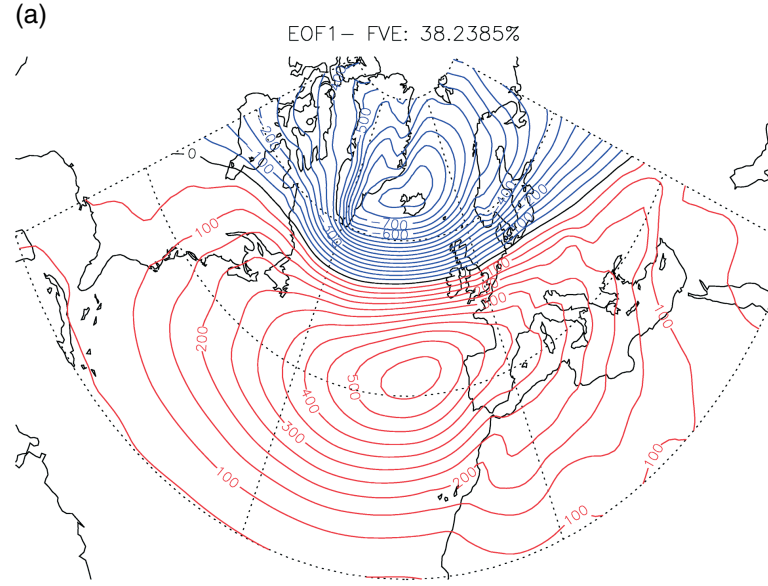

(c)

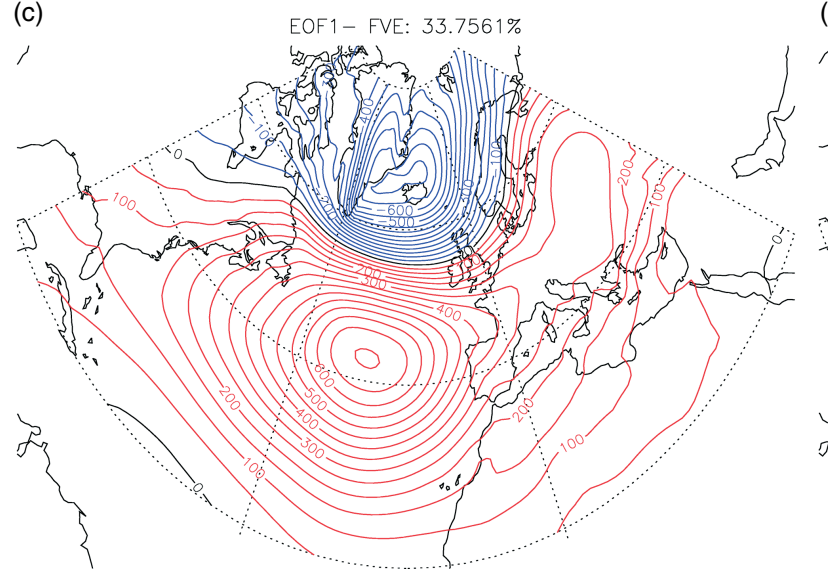

(b)

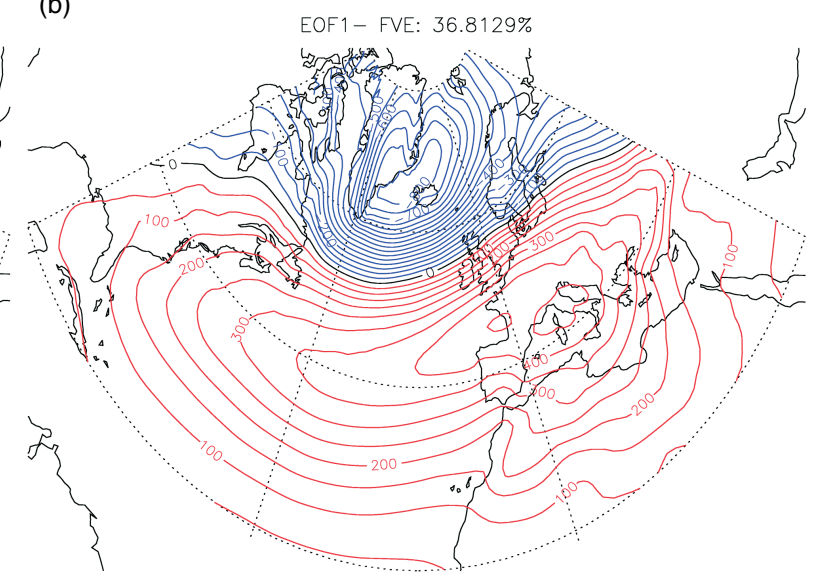

(d)

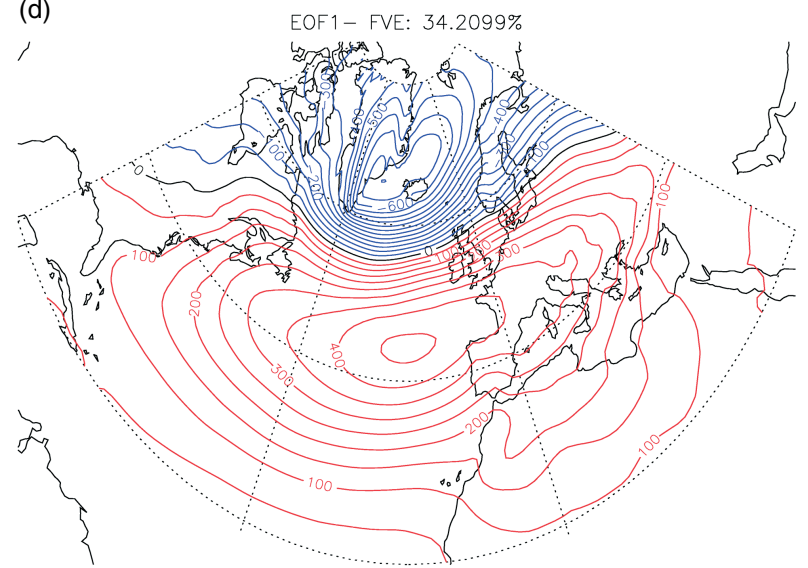

Figure 9. The leading mode of variability (EOF1) of winter (December, January and February) monthly mean MSLP anomalies for (a) ERA-40 (45 years), (b) HiGEM (50 years), (c) HiGAM control run (19 years) and (d) HiGAM perturbed run (19 years). The magnitude of pattern (in Pa) is for 1 standard deviation of the index.

Folland, 2002). The NAO for the control experiment shown in Figure 9(c) highlights that the atmospheric model does not provide a perfect representation of the NAO, even when forced by observed SST. In its positive phase the NAO highpressure lobe of the dipole is too large in magnitude, more circular in shape and centred on the middle of the Atlantic basin. The impact of the SST perturbation on the NAO in the perturbed experiment is shown in Figure 9(d). Comparing Figures 9(c) and (d) we see that when the SST perturbation is applied the centres of action of the MSLP dipole weaken and therefore the meridional gradient in pressure across the Atlantic also weakens. The centre of the high-pressure lobe of the dipole also shifts slightly to the east.

The differences in the NAO pattern in HiGEM compared to ERA-40 are similar to the changes in pattern between the perturbation and the control atmosphere-only model experiments. This suggests that reducing the SST bias in the coupled model would likely also improve the spatial pattern of the NAO.

\section{Conclusions}

This study has investigated the impact of the North Atlantic SST bias found in the HiGEM model on the model winter mean state and variability. This SST bias is common to many coupled climate models. In winter HiGEM has an SST bias that is over $8 \mathrm{~K}$ too cold to the east of the Grand Banks of Newfoundland because the path of the North Atlantic Current is too zonal. There is also a warm bias of over $6 \mathrm{~K}$ near the east coast of North America because the Gulf Stream in the model separates further north than observed. Using an atmosphere-only version of the coupled model-HiGAM-we have carried out experiments with and without the North Atlantic SST bias to test our hypothesis that this can explain the biases in the large-scale atmospheric circulation in HiGEM.

We summarize the main findings of our results below. The SST bias in the North Atlantic is likely the major cause of the coupled model atmospheric circulation bias in the North Atlantic and European region. Our results show that there is a qualitative and quantitative agreement between the largescale atmospheric response in the HiGAM experiments and the coupled model bias.

The transient eddy response to the SST perturbation plays a key role in the mean winter atmospheric response in the North Atlantic. There is a downstream equivalent barotropic highpressure anomaly in the mid North Atlantic, suggesting that there is an eddy-dominated response to the SST perturbation. The response pattern in the atmosphere-only (HiGAM) experiments is $\sim 5^{\circ}$ to the north of the coupled model (HiGEM) bias (compared to reanalysis data) and is likely due to the differences in mean state between HiGEM and HiGAM and the local heating perturbation caused by precipitation biases in the sub-polar gyre region, which are not caused by the North Atlantic SST biases.

The SST bias also has an impact on the model's atmospheric variability. The positive bias in storm track strength in HiGEM is also found when the SST bias is 
applied to HiGAM. This appears to be due to changes in the SST gradient near the coast. This suggests that the warm SST bias, caused by the modelled Gulf Stream separating from the coast further north than Cape Hatteras, plays a key role in the increased storm activity. The cold SST bias east of Newfoundland acts to reduce the eddy activity further downstream.

A response to the SST perturbation is also seen in the North Atlantic Oscillation (NAO). The centre of action of the high-pressure lobe of the NAO pattern (in its positive phase) moves to the east. The magnitude of the high-pressure centre is also reduced by about $40 \%$, which therefore reduces the gradient between the high and low centres, thus reducing the variability in the jet strength. These results are similar to the biases we find in the coupled model's representation of the NAO, implying that the SST biases are also important for the modelled large-scale variability.

Both the warm and cold components of the SST bias in the HiGEM coupled model are important for explaining changes in the mean state and the variability. The key implication of this work is that biases in winter atmospheric circulation over Europe in coupled climate models could be substantially reduced if the North Atlantic SST biases were removed. The potential for improved ocean state to alleviate Atlantic blocking errors has been seen in recent work by Scaife et al. (2011).

\section{Acknowledgements}

The authors wish to thank David Brayshaw for insightful discussions and comments on earlier drafts of the paper. They also acknowledge the European Centre for MediumRange Weather Forecasts and the NCAS British Atmospheric Data Centre for provision of the reanalysis data. SK was funded on NERC grant NE/E522575/1 and by the UK Met Office.

\section{References}

Balmaseda MA, Ferranti L, Molteni F, Palmer TN. 2010. Impact of 2007 and 2008 Arctic ice anomalies on the atmospheric circulation: implications for long-range predictions. Q. J. R. Meteorol. Soc. 136: 1655-1664.

Brayshaw DJ, Hoskins B, Blackburn M. 2008. The storm-track response to idealized SST perturbations in an Aquaplanet GCM. J. Atmos. Sci. 65: $2842-2860$.

Brayshaw DJ, Hoskins B, Blackburn M. 2011. The basic ingredients of the North Atlantic storm track. Part II: Sea surface temperatures. J. Atmos. Sci. 68: 1784-1805.

Bryan FO, Hecht MW, Smith RD. 2007. Resolution convergence and sensitivity studies with North Atlantic circulation models. Part I: The western boundary current system. Ocean Model 16: 141-159.

Duchon CE. 1979. Lanczos filtering in one and two dimensions. J. Appl. Meteorol. 18: 1016-1022.

Eden C, Greatbatch RJ, Böning CW. 2004. Adiabatically correcting an eddy-permitting model using large-scale hydrographic data: application to the Gulf Stream and the North Atlantic Current. J. Phys. Oceanogr. 34: 701-719.

Frankignoul C. 1985. Sea surface temperature anomalies, planetary waves, and air-sea feedback in the middle latitudes. Rev. Geophys. 23: $357-390$.

Hoskins BJ, Karoly DJ. 1981. The steady linear response of a spherical atmosphere to thermal and orographic forcing. J. Atmos. Sci. 38: 1179-1196.

Hurrell JW, Hack JJ, Shea D, Caron JM, Rosinski J. 2008. A new sea surface temperature and sea ice boundary dataset for the Community Atmosphere Model. J. Climate 21: 5145-5153.

Kushnir Y, Held IM. 1996. Equilibrium atmospheric response to North Atlantic SST anomalies. J. Climate 9: 1208-1220.

Kushnir Y, Robinson WA, Bladé I, Hall NMJ, Peng S, Sutton R. 2002. Atmospheric GCM response to extratropical SST anomalies: synthesis and evaluation. J. Climate 15: 2233-2256.

Large WG, Danabasoglu G. 2006. Attribution and Impacts of UpperOcean Biases in CCSM3. J. Climate 19: 2325-2346.

Randall DA, Wood RA, Bony S, Colman R, Fichefet T, Fyfe J, Kattsov V, Pitman A, Shukla J, Srinivasan J, Stouffer RJ, Sumi A, Taylor KE. 2007. Climate models and their evaluation. In Climate Change 2007: The Physical Science Basis. Contribution of Working Group I to the Fourth Assessment Report of the Intergovernmental Panel on Climate Change, Solomon S, Qin D, Manning M, Chen Z, Marquis M, Averyt KB, Tignor M, Miller HL (eds). Cambridge University Press: Cambridge, UK; 591-648.

Rodwell MJ, Folland CK. 2002. Atlantic air-sea interaction and seasonal predictability. Q. J. R. Meteorol. Soc. 128: 1413-1443.

Scaife AA, Copsey D, Gordon C, Harris C, Hinton T, Keeley S, O’Neill A, Roberts M, Williams K. 2011. Improved Atlantic winter blocking in a climate model, Geophys. Res. Lett. 38: L23703, DOI: 10.1029/2011GL049573.

Shaffrey LC, Stevens I, Norton WA, Roberts MJ, Vidale PL, Harle JD, Jrrar A, Stevens DP, Woodage MJ, Demory ME, Donners J, Clark DB, Clayton A, Cole JW, Wilson SS, Connolley WM, Davies TM, Iwi AM, Johns TC, King JC, New AL, Slingo JM, Slingo A, Steenman-Clark L, Martin GM. 2009. U.K. HiGEM: The new U.K. High-Resolution Global Environment Model: model description and basic evaluation. J. Climate 22: 1861-1896.

Smith RD, Maltrud ME, Bryan FO, Hecht MW. 2000. Numerical simulation of the North Atlantic Ocean at $1 / 10^{\circ}$. J. Phys. Oceanogr. 30: $1532-1561$.

Uppala SM, Kållberg PW, Simmons AJ, Andrae U, da Costa Bechtold V, Fiorino M, Gibson JK, Haseler J, Hernandez A, Kelly GA, Li X, Onogi K, Saarinen S, Sokka N, Allan RP, Andersson E, Arpe K, Balmaseda MA, Beljaars ACM, van de Berg L, Bidlot J, Bormann N, Caires S, Chevallier F, Dethof A, Dragosavac M, Fisher M, Fuentes M, Hagemann S, Hólm E, Hoskins BJ, Isaksen L, Janssen PAEM, Jenne R, McNally AP, Mahfouf JF, Morcrette J-J, Rayner NA, Saunders RW, Simon P, Sterl A, Trenberth KE, Untch A, Vasiljevic D, Viterbo P, Woollen J. 2005. The ERA-40 re-analysis. Q. J. R. Meteorol. Soc. 131: 2961-3012.

Wallace JM, Gutzler DS. 1981. Teleconnections in the geopotential height field during the Northern Hemisphere winter. Mon. Weather Rev. 109: 784-812.

Weese SR, Bryan FO. 2006. Climate impacts of systematic errors in the simulation of the path of the North Atlantic Current. Geophys. Res. Lett. 33: L19708, DOI: 10.1029/2006GL027669.

Willebrand J, Barnier B, Boening C, Dieterich C, Killworth PD, Le Provost C, Jia Y, Molines J-M, New AL. 2001. Circulation characteristics in three eddy-permitting models of the North Atlantic. Prog. Oceanogr. 48: 123-161.

Xie P, Arkin P. 1997. Global precipitation: a 17-year monthly analysis based on gauge observations, satellite estimates, and numerical model outputs. Bull. Am. Meteorol. Soc. 78: 2539-2558. 